\title{
Nutritive value of Eurolysine bacterial protein and Pekilo protein for growing pigs
}

\author{
MATTI NÄSI \\ Department of Animal Husbandry, University of Helsinki, 00710 Helsinki 71
}

\begin{abstract}
Digestibility and balance trials were performed with six growing pigs, to evaluate the nutritive value and protein utilization of Eurolysine bacterial protein and Pekilo protein used to replace $50 \%$ or $100 \%$ of soybean supplement in a barley-based diet. Eurolysine had a high content of crude protein, 67.8 $\%$ of $\mathrm{DM}$, and was rich in lysine, $8.3 \mathrm{~g} / 16 \mathrm{~N}$, and the corresponding values for Pekilo were $49.5 \%$ and 5.5 $\mathrm{g} / 16 \mathrm{~g} \mathrm{~N}$. The diets containing Eurolysine had lower digestibilities than those with Pekilo or soybean meal. With Eurolysine the digestibility values for crude protein, ether extract and $\mathrm{N}$-free extract (NFE) were, respectively, $64.3 \%, 35.4 \%$ and $76.5 \%$, and with Pekilo $74.8 \%, 28.5 \%$ and $79.4 \%$. The feed values for Eurolysine were $0.82 \mathrm{FU} / \mathrm{kg}, 509 \mathrm{~g} \mathrm{DCP} / \mathrm{kg}$ and $12.0 \mathrm{MJ} \mathrm{ME} / \mathrm{kg} \mathrm{DM}$, and those for Pekilo 0.90 $\mathrm{FU} / \mathrm{kg}, 409 \mathrm{~g} \mathrm{DCP} / \mathrm{kg}$ and $12.6 \mathrm{MJ} \mathrm{ME} / \mathrm{kg}$ DM. The urinary nitrogen excretion was lower with Eurolysine than with the other supplements, and the nitrogen retention and the biological values were higher $(\mathrm{P}<0.05)$. Eurolysine is well suited as a protein supplement in pig feeding because of its high content of lysine. Combined with barley the protein in Eurolysine gave a high biological value.
\end{abstract}

\section{Introduction}

Eurolysine is the trade name of a single cell protein (SCP), a by-product of Llysine fermentation on a beet molasses substrate. It is of bacterial origin and is produced by harvesting dead cells of an organism classified as Bacterium lactofermentum (ANON. 1979). The Eurolysine bacterial mass has a high content of crude protein and is also rich in lysine.

Numerous experiments have been conducted with SCP of various origins as a protein source for pigs, and promising results have been achieved with bacterial protein (D'MELLO et al. 1976, WHITTEMORE and MOFFAT 1976, BRAUDE et al. 1977, HANSEN 1981, 1982). In Finland Pekilo protein and Torula yeast, produced on sulphite spent liquor, have been investigated as protein supplements for pigs with good results (ALAVIUHKOLA et al. 1975, 1979, SALO and PEKKARINEN 1981).

In the present metabolic experiment Eurolysine bacterial protein and Pekilo protein were used as supplements in diets for growing pigs, and their value as protein sources was compared with that of soybean meal. 
Table 1. Percentage composition of diets containing soybean meal, Eurolysine or Pekilo as protein supplement.

\begin{tabular}{lccccc} 
Ingredients & \multicolumn{5}{c}{ Protein supplement } \\
\cline { 2 - 6 } & $\begin{array}{c}\text { Soybean } \\
100 \%\end{array}$ & $\begin{array}{c}\text { Soybean } 50 \% \\
\text { Eurolysine } 50 \%\end{array}$ & $\begin{array}{c}\text { Eurolysine } \\
100 \%\end{array}$ & $\begin{array}{c}\text { Eurolysine } 50 \% \\
\text { Pekilo } 50 \%\end{array}$ & Pekilo $100 \%$ \\
\hline Barley meal & 86 & 86 & 86 & 86 & 86 \\
Soybean meal & 14 & 7 & - & - & - \\
Eurolysine & - & 5 & 10 & 5 & 13 \\
Pekilo & - & - & - & 7 & - \\
Wheat starch & - & 2 & 4 & 2 & 1 \\
\hline
\end{tabular}

\section{Materials and Methods}

Digestibility and balance trials were carried out with six male castrated Landrace pigs during the growth period from 37 to $65 \mathrm{~kg}$, using a total collection method. The experiment was designed as two $3 \times 3$ Latin squares, to compare soybean meal, Eurolysine bacterial protein and Pekilo protein used at two levels of supplementation. The basic feed was barley milled with a 3-mm sieve, with daily supplements of $40 \mathrm{~g}$ mineral mixture (Seleni-Terki) and $15 \mathrm{~g}$ vitamin mixture (Vitamiini-Nasu). The rations used in the trials are shown in Table 1. Each test period lasted 15 days: the transition period between the diets was three days, and the standardization period and the collection period were each six days.

The pigs were kept in metabolic cages, which allowed separate collection of faeces and urine. These were collected twice daily and representative samples were frozen and stored until analysis. The pigs were fed twice daily according to the PARTANEN (1970) standard scale, based on liveweight. The diet was mixed with water $(1: 2.5 \mathrm{w} / \mathrm{v})$ immediately before feeding. Water was given after feeding. Feed spillages were collected and substracted from the ration. The daily rations were in the collection periods $1.8,2.2$. and $2.6 \mathrm{~kg}$. The pigs were weighed before and after the collection period.

Chemical analyses of feeds and faeces were performed according to official procedures. The amino acid composition was analysed with a gas chromatograph (Hewlett Packard 5710A) by the method of NÄSI and HUIDA (1982).

\section{Results and Discussion}

The chemical composition of the experimental feeds is presented in Table 2. The crude protein content of Eurolysine was high, $67.8 \%$ of DM, and the true protein content was $51.4 \%$. The ether extract was also fairly high for a single cell product, $9.3 \%$ after $\mathrm{HCl}$ hydrolysis. The lysine content of Eurolysine exceeded the values of Pekilo and soybean by 2-3 g, which makes it a specially valuable complement to cereal protein. It is deficient in 
Table 2. Chemical composition of the experimental feeds.

\begin{tabular}{|c|c|c|c|c|}
\hline Percentage of dry matter & Eurolysine & Pekilo & Soybean meal & Barley \\
\hline Dry matter (\%) & 95.8 & 96.8 & 95.0 & 94.1 \\
\hline Ash & 4.7 & 6.2 & 6.5 & 2.7 \\
\hline Crude protein & 67.8 & 49.5 & 46.2 & 11.1 \\
\hline True protein & 51.4 & 44.3 & 44.8 & 9.6 \\
\hline Ether extract & 7.5 & 1.2 & 1.6 & 2.5 \\
\hline Ether extract, $\mathrm{HCl}$ & 9.3 & 4.1 & 2.8 & 3.5 \\
\hline Crude fibre & 0.9 & 7.3 & 8.7 & 4.8 \\
\hline NFE & 19.1 & 35.8 & 37.0 & 78.8 \\
\hline \multicolumn{5}{|l|}{ Amino acids g/ $16 \mathrm{~g} \mathrm{~N}$} \\
\hline Alanine & 7.0 & 5.6 & 4.4 & 4.1 \\
\hline Arginine & 3.4 & 4.6 & 6.6 & 4.4 \\
\hline Aspartic acid & 7.1 & 7.1 & 11.1 & 5.6 \\
\hline Glutamic acid & 9.7 & 11.5 & 17.4 & 20.2 \\
\hline Glycine & 3.7 & 4.2 & 4.3 & 4.0 \\
\hline Histidine & 0.9 & 1.2 & 2.1 & 2.2 \\
\hline Isoleucine & 3.6 & 3.5 & 5.0 & 3.6 \\
\hline Leucine & 5.8 & 6.1 & 7.7 & 6.7 \\
\hline Lysine & 8.3 & 5.5 & 5.9 & 3.5 \\
\hline Methionine & 0.6 & 0.5 & 1.0 & 1.2 \\
\hline Phenylalanine & 3.0 & 3.3 & 5.0 & 4.6 \\
\hline Proline & 2.6 & 3.5 & 5.1 & 9.4 \\
\hline Serine & 3.0 & 3.7 & 5.3 & 4.1 \\
\hline Threonine & 3.7 & 3.7 & 4.3 & 3.6 \\
\hline Tyrosine & 2.1 & 2.7 & 3.5 & 3.0 \\
\hline Valine & 4.5 & 4.3 & 5.2 & 5.0 \\
\hline
\end{tabular}

sulphur-containing amino acids and the methionine content was only $0.6 \mathrm{~g} /$ $16 \mathrm{~g} \mathrm{~N}$. It had a fairly high content of phosphorus, $7.7 \mathrm{~g}$, but low contents of calcium and magnesium, $1.3 \mathrm{~g}$ and $0.2 \mathrm{~g} / \mathrm{kg} \mathrm{DM}$, respectively.

The digestibility coefficients of the various diets supplemented with the different protein sources are shown in Table 3 . The crude protein digestibility in the diet supplemented with Eurolysine alone was $9 \%$ lower than in the diet with soybean meal and $4 \%$ lower than in that with Pekilo, but the differences were not statistically significant $(P>0.05)$. The true protein digestibilities differed significantly $(\mathrm{P}<0.05)$ between the protein supplements. The crude fat and crude fibre digestibilities were also lower $(\mathrm{P}>0.05)$ in the diets with Eyrolysine supplementation than in the others. The digestibility coefficients for Eurolysine calculated with regression equations from the two levels of supplementation were: crude protein $64.3 \%$, ether extract $35.4 \%$, and NFE $76.5 \%$. The feed values for Eurolysine were $0.82 \mathrm{FU} / \mathrm{kg}$, $509 \mathrm{~g} \mathrm{DCP} / \mathrm{kg}$ and $12.0 \mathrm{MJ} \mathrm{ME} / \mathrm{kg} \mathrm{DM}$. The corresponding digestibilities for Pekilo were: crude protein $74.8 \%$, ether extract $28.5 \%$ and NFE $79.4 \%$. The feed values were $0.90 \mathrm{FU} / \mathrm{kg}, 402 \mathrm{~g} \mathrm{DCP} / \mathrm{kg}$ and $12.6 \mathrm{MJ} \mathrm{ME} / \mathrm{kg} \mathrm{DM}$ (1 $\mathrm{FU}=0.7 \mathrm{~kg}$ starch).

Pepsin-HCl-soluble protein was $\mathbf{5 2 . 9} \%$ of crude protein for Eurolysine, $69.0 \%$ for Pekilo and $92.8 \%$ for soybean meal. 
Table 3. Digestibility coefficients for diets with and without supplementation by Eurolysine bacterial protein and Pekilo protein.

Protein supplement

\begin{tabular}{|c|c|c|c|c|c|c|c|c|c|c|}
\hline & \multicolumn{2}{|c|}{$\begin{array}{c}\text { Soybean meal } \\
100 \%\end{array}$} & \multicolumn{2}{|c|}{$\begin{array}{c}\text { Soybean meal } 50 \% \\
\text { Eurolysine } 50 \%\end{array}$} & \multicolumn{2}{|c|}{ Eurolysine $100 \%$} & \multicolumn{2}{|c|}{$\begin{array}{c}\text { Eurolysine } 50 \% \\
\text { Pekilo } 50 \%\end{array}$} & \multicolumn{2}{|c|}{ Pekilo $100 \%$} \\
\hline & $\tilde{\mathbf{x}}$ & s.d. & $\tilde{\mathbf{x}}$ & s.d. & $\overline{\mathbf{x}}$ & s.d. & $\overline{\mathbf{x}}$ & s.d. & $\overline{\mathbf{x}}$ & s.d. \\
\hline Dry matter & $81.8^{2}$ & 1.3 & $80.7^{2}$ & 1.4 & $79.2^{2}$ & 1.0 & $80.5^{2}$ & 0.3 & $79.9^{2}$ & 1.8 \\
\hline Ash & $52.3^{2}$ & 2.2 & $51.1^{2}$ & 1.0 & $51.9^{2}$ & 2.8 & $55.0^{a}$ & 1.7 & $51.0^{2}$ & 2.0 \\
\hline Organic matter & $83.5^{2}$ & 1.2 & $82.2^{2}$ & 1.5 & $80.6^{2}$ & 0.9 & $81.9^{\mathrm{a}}$ & 0.3 & $81.5^{2}$ & 1.7 \\
\hline Crude protein & $79.0^{2}$ & 5.5 & $75.5^{2}$ & 4.2 & $70.2^{2}$ & 3.5 & $72.7^{2}$ & 0.5 & $74.2^{2}$ & 4.7 \\
\hline True protein & $83.9^{2}$ & 4.1 & $79.0^{2}$ & 4.3 & $72.0^{\mathrm{b}}$ & 2.8 & $75.2^{\mathrm{ab}}$ & 1.4 & $78.3^{2}$ & 5.4 \\
\hline Crude fat & $50.2^{2}$ & 3.5 & $46.1^{2}$ & 2.0 & $43.2^{2}$ & 4.8 & $48.4^{\mathrm{a}}$ & 3.9 & $46.9^{2}$ & 4.2 \\
\hline Crude fibre & $20.2^{2}$ & 2.8 & $10.8^{4}$ & 7.5 & $6.1^{2}$ & 4.9 & $16.7^{2}$ & 2.7 & $26.3^{a}$ & 2.4 \\
\hline NFE & $90.8^{2}$ & 0.3 & $90.4^{a}$ & 0.9 & $89.4^{2}$ & 0.3 & $90.0^{2}$ & 0.5 & $88.9^{2}$ & 1.0 \\
\hline
\end{tabular}

Differences between means with dfifferent letters were statistically significant $(a, b, P<0.05)$.

The digestibilities of Eurolysine and Pekilo were rather low in these experiments compared with the results reported from previous trials with bacterial protein and Pekilo or some yeasts. The crude protein digestibilities usually recorded are 80-90\% (SCHULZ and OSLAGE 1976, D'MELLO et al. 1976, WHITTEMORE and MOFFAT 1976, BRAUDE et al. 1977, HANSEN 1981, SALO and PEKKARINEN 1981). However, HANSEN (1981) also obtained rather low values with Pekilo, $67.9 \%$ for digestible crude protein, and with bacterial protein, $62,5 \%$ for digestible organic matter. In most of the earlier digestibility experiments the SCP supplements have been higher than in the present study, and the protein digestibilities have been noted to increase with intakes of protein in excess of the requirement (BRAUDE et al. 1977, JUST et al. 1980). The reason for low digestibility in the case of Eurolysine might also lie in the preparation of granules from the bacterial mass. The cell wall can also remain largely intact and the contents of the cells will then be less accessible to the digestive system.

Estimates of the digestibility of individual amino acids in different diets are presented in the paper of NÄSI and HUIDA (1982). The values of most amino acids follow the trend of crude protein digestibility.

The nitrogen balance, biological value and daily gain of pigs on the various experimental diets are shown in Table 4. The nitrogen excretion in faeces was greater on the diets with Eurolysine, which is reflected in the lower crude protein digestibility. In contrast, the urinary nitrogen excretion was lower on the Eurolysine diets. The nitrogen retention was significantly higher $(\mathrm{P}<0.05)$ on the diet supplemented with Eurolysine than when soybean meal or Pekilo were used as the sole protein supplements. Superior values were achieved with the diet supplemented with both Eurolysine and Pekilo. The nitrogen retention was $59.5 \%$ of absrorption, which was $10 \%$ greater than with other protein sources. The biological value was significantly higher $(\mathrm{P}<0.05)$ on the Eurolysine diet than with the soybean meal or Pekilo 
Table 4. Nitrogen balance, biological value and daily gain of pigs on diets containing soybean meal, Eurolysine and Pekilo as protein supplements.

\begin{tabular}{|c|c|c|c|c|c|}
\hline & \multicolumn{5}{|c|}{ Protein supplement } \\
\hline & \multirow{2}{*}{$\begin{array}{r}\text { Soybean } \\
100 \%\end{array}$} & \multirow{2}{*}{\multicolumn{2}{|c|}{$\begin{array}{l}\text { Soybean } 50 \% \text { Eurolysine } \\
\text { Eurolysine } 50 \% \quad 100 \%\end{array}$}} & \multicolumn{2}{|c|}{ Eurolysine $50 \%$ Pekilo } \\
\hline & & & & Pekilo $50 \%$ & $100 \%$ \\
\hline \multicolumn{6}{|l|}{ Nitrogen } \\
\hline Intake, $\mathrm{g} / \mathrm{d}$ & 49.0 & 49.7 & 50.5 & 49.0 & 48.9 \\
\hline Faeces, g/d & 10.1 & 12.2 & $15.1^{2}$ & $13.6^{\mathrm{ab}}$ & $12.5^{\mathrm{b}}$ \\
\hline Absorbed, g/d & 38.9 & 37.5 & 35.4 & 35.4 & 36.4 \\
\hline Urine, $\mathrm{g} / \mathrm{d}$ & $20.3^{2}$ & $17.1^{\mathrm{ab}}$ & $14.4^{\mathrm{b}}$ & 13.8 & 19.2 \\
\hline Retained, g/d & $18.6^{\mathrm{b}}$ & $20.4^{2}$ & $21.0^{2}$ & $21.6^{2}$ & $17.2^{\mathrm{b}}$ \\
\hline$\%$ of intake & $38.2^{\mathrm{b}}$ & $41.4^{2}$ & $41.4^{2}$ & 44.1 & 35.7 \\
\hline$\%$ of absorbtion & $48.9^{b}$ & $55.4^{\mathrm{ab}}$ & $59.5^{\mathrm{a}}$ & $61.0^{2}$ & $48.7^{b}$ \\
\hline Biological value & $65.4^{\mathrm{b}}$ & $70.9^{\mathrm{ab}}$ & $74.8^{\mathrm{a}}$ & $75.7^{2}$ & $65.8^{b}$ \\
\hline Daily gain, g/d & 698 & 714 & 798 & 774 & 691 \\
\hline
\end{tabular}

Differences between means with different letter were statistically significant $(a, b, P<0.05)$.

supplements. The daily gain of the pigs follows the nitrogen retention and biological value.

On the Eurolysine diet the pigs received digestible lysine at the rate of 13.8 $\mathrm{g} / \mathrm{d}$, on the soybean diet they received $11.4 \mathrm{~g} / \mathrm{d}$ and on the Pekilo diet $10.0 \mathrm{~g} /$ $\mathrm{d}$. The corresponding digestible threonine intakes were $8.6 \mathrm{~g} / \mathrm{d}, 9.8 \mathrm{~g} / \mathrm{d}$ and $8.6 \mathrm{~g} / \mathrm{d}$.

Nucleic acids, particularly RNA, represent a quantitatively significant $\mathrm{N}$ fraction in microbial protein, $16-24 \%$ of the total nitrogen in bacteria, but they have limited value as a protein source for single-stomach animals (ROTH and KIRCHGESSNER 1980).

For an overall evaluation of a protein source, the amount of protein which can be effectively utilized by the animal is of great importance. Barley and other cereals are low in lysine. Addition of Eurolysine bacterial protein gives satisfactory values for nitrogen retention and utilization and daily gain in pigs compared with soybean meal or Pekilo. The high lysine content of Eurolysine is very promising. Eurolysine is poor in sulphur-containing amino acids, which may have been the reason for the poorer performance of laying hens fed on diets containing gradually increasing levels of this bacterial protein (NÄSI 1982).

Acknowledgements. The author is indebted to Ms. Leila Korpihalkola, M.Sc. \& Agr. and Mr. Timo Laitinen for technical assistance, and to Berner Oy for financial support. 


\section{References}

ALAVIUHKOLA, T. 1979. Experiences on feeding pigs with Pekilo. Research reports of Pekilosymposium. Agric. Res. Centre, Inst. Anim. Husb. Rep. 12: 33-45.

- , KORHONEN, I., PARTANEN, J. \& LAMPILA, M. 1975. Pekilo protein in the nutrition of growing finishing pigs. Acta Agric. Scand. 25: 301-305.

ANON. 1979. Introduction of Eurolysine. Orsan. Mimeogr. 15 p.

BRAUDE, R., HOSKING, Z. D., MITCHELL, K. G., PLONKA, S. \& SAMBROOK, I. E. 1977. Pruten, a new source of protein for growing pigs. I. Metabolic experiment: utilization of nitrogen. Livest. Prod. Sci. 4: 79-89.

D'MELLO, J. P. F., PEERS, D. G. \& WHITTEMORE, C. T. 1976. Utilization of dried microbial cells grown on methanol in a semi-purified diet for growing pigs. Br. J. Nutr. 36: 403-410.

HANSEN, J. T. 1981. Bioproteins in the feeding of growing finishing pigs in Norway. 1. Chemical composition, nutrient digestibility and protein quality of Pruteen, Torpina, Pekilo and a methanolbased yeast product (Pichia Aganobii). Z. Tierphysiol. Tierernähr u. Futtermittelk. 46: $182-196$.

- 1982. Bioproteins in the feeding of growing-finishing pigs in Norway. 2. Pruteen replacing soybean meal as a protein supplement in cereal diet. Z. Tierphysiol. Tierernähr. u. Futtermittelk. 47: $21-34$.

JUST, A., SAUER, W. C. \& JØRGENSEN, H. 1980. The influence of diet composition on the apparent ileal and faecal digestibility of protein and amino acids in pigs. Proc. $3^{\text {rd }}$ EAAP symp. on Protein Metabolism and Nutrition N:o 27: 215-219.

NÄSI, M. 1982. Performance of laying hens on diets containing Eurolysine bacterial protein or Pekilo protein. J. Scient. Agric. Soc. Finl. 54: 271-278.

— \& HUIDA, L. 1982. Digestibility of amino acids in diets including Eurolysine bacterial protein or Pekilo protein with special reference to a gas chromatograph method used in amino acid determination. J. Scient. Agric. Soc. Finl. 54: 279-285.

PARTANEN, J. 1976. Lihasikojen uudet viikottaiset ry-normit. Sika 205: 6-17.

ROTH, F. X. \& KIRCHGESSNER, M. 1980. Alimentär zugeführte Nukleinsäuren in N-Stoffwechsel von Monogastriden. Arch. Tierernähr. 30: 77-88.

SALO, M-L. \& PEKKARINEN, E. 1981. Nutritive value for growing pigs of pekilo protein and torula yeast grown in spent sulphite liquor. J. Scient. Agric. Soc. Finl. 53: 52-56.

SCHULZ, E. \& OSLAGE, H. J. 1976. Composition and nutritive value of single cell protein (SCP). Anim. Feed Sci. Technol. 1: 9-24.

WHITTEMORE, C. T. \& MOFFAT, I. W. 1976. The digestibility of dried microbial cells grown on methanol in diets for growing pigs. J. agric. Sci., Camb. 86: 407-410.

Ms. received July 19,1982

\section{Eurolysine bakteeriproteiinin ja pekiloproteiinin rehuarvo lihasialla}

\section{Matti Näsi}

Helsingin yliopisto, kotieläintieteen laitos. 00710 Helsinki 71

Sulavuus- ja tasekokeessa tutkittiin kahden mikrobiproteiinituotteen eurolysine bakteeriproteiinin ja pekiloproteiinin rehuarvo ja valkuaisen hyväksikäyttö lihasialla. Eurolysinen valkuaispitoisuus oli $67.8 \%$ ja pekilon $49.5 \%$ kuiva-aineessa ja lysiinipitoisuudet olivat 8.3 ja $5.5 \mathrm{~g} / 16 \mathrm{~N}$. Eurolysinellä ja pekilolla korvattiin $50 \%$ ja $100 \%$ rehuseoksen soijalisästä. 
Eurolysinedieetin sulavuus oli alempi kuin pekiloa tai soijaa sisältävän. Eurolysinen raakavalkuaisen, raakarasvan ja typettömien uuteaineiden sulavuudet olivat $64.3 \%, 35.4 \%$ ja $76.5 \%$ ja pekilon vastaavasti $74.8 \%, 28.5 \%$ ja $79.4 \%$. Rehuarvot olivat eurolysinellä $0.82 \mathrm{ry} / \mathrm{kg}, 509$ $\mathrm{g}$ srv $/ \mathrm{kg}$, ja $12.0 \mathrm{MJ} \mathrm{ME} / \mathrm{kg}$ ka, ja pekilolla $0.90 \mathrm{ry} / \mathrm{kg}, 402 \mathrm{~g}$ srv $/ \mathrm{kg}$ ja $12.6 \mathrm{MJ} \mathrm{ME} / \mathrm{kg} \mathrm{ka}$. Virtsassa erittyvän typen määrä oli eurolysine ruokinnalla alempi ja typen pidättyminen ja valkuaisen biologinen arvo olivat korkeampia verrattuna pekiloon ja soijaan. Eurolysine osoittautui hyväksi valkuaislähteeksi lihasikojen ruokinnassa erityisesti korkean lysiinipitoisuuden takia. 